\title{
FAKTOR-FAKTOR YANG BERHUBUNGAN DENGAN KUNJUNGAN IBU BALITA KE POSYANDU DI DESA MEKARSARI KABUPATEN LEBAK PROVINSI BANTEN TAHUN 2016
}

\author{
*Darti Rumiatun, *Dina Sri Mawaddah
}

\begin{abstract}
Abstrak
Derajad kesehatan di indonesia masih rendah, hal itu dapat diukur dengan indikator di antaranya adalah angka kematian bayi (AKB) dan angka kematian ibu (AKI).Berbagai faktor dapat mempengaruhi naik dan turunnya AKB dan AKI, diantaranya belum di manfaatkannya sarana pelayanan kesehatan seperti posyandu secara optimal oleh masyarakat. Di Provinsi Banten angka kematian ibu dan bayi menduduki posisi kelima secara nasional.Sedangkan Untuk dikabupaten Lebak kematian bayi dan balita menduduki urutan kedua dari 8 kabupaten yang ada di banten yaitu sebesar 383. Banyak Faktor yang mempengaruhi kunjungan ibu dan balita keposyandu diantaranya umur balita, jarak tempuh, pekerjaan, pendidikan dan pengetahuan ibu.
\end{abstract}

Tujuan dari penelitian ini adalah untuk mengetahui faktor - faktor yang berhubungan dengan kunjungan ibu balita keposyandu di desa mekarsari lebak banten. Penelitian ini menggunakan jenis penelitian observasional analitik dengan metode pendekatan cross sectional. Total populasi 153 balita dan 113 sampel yang dipilih dengan cara Random Sampling. Instrument yang digunakan adalah kuesioner. Analisis data dalam penelitian ini terdiri dari analisis univariat,untuk mengetahui distribusi frekuensi dari masingmasing variable, Analisis bivariat untuk mengetahui hubungan antara varibel independen dan variable dependen dengan menggunakan uji chi squre di maknai dengan bila didapatkan nilai $\mathrm{p}<0,05 \mathrm{H0}$ diterima atau ada faktor - faktor yang berhubungan dengan kunjungan ibu dan balita ke posyandu dan apabila nilai $\mathrm{p}>0,05 \mathrm{H} 0$ ditolak atau tidak ada faktor - faktor yang berhubungan dengan kunjungan ibu dan balita ke posyandu,dan analisis multivariat untuk mengetahui faktor yang paling dominan yang berhubungan dengan kunjungan balita ke posyandu dengan menggunakan uji regresi logistic

Hasil penelitian didapatkan ibu balita yang berprilaku baik berkunjung ke Posyandu ke posyandu masih rendah sebanyak $43,4 \%$. Ada 3 variabel yang secara statistic berhubungan dengan perilaku kunjungan ibu balita ke posyandu yaitu pendidikan, pengetahuan dan umur anak. Berdasarkan hasil uji regresi logistic factor yang paling berpengaruh terhadap perilaku kunjungan ibu ke posyandu adalah umur anak.

Disarankan untuk melakukan dan meningkatkan monitoring upaya promosi kesehatan dengan supervise langsung keposyandu dan memberikan penyuluhan kepada masyarakat tentang kegiatan yang ada diposyandu.

Kata kunci : Kunjungan Ibu balita, Posyandu

*Poltekkes Kemenkes Banten 


\section{Pendahuluan}

Derajad kesehatan di Indonesia masih rendah, dimana 153.681 bayi mati setiap tahun. Itu berarti setiap harinya ada 421 orang bayi yang mati sama dengan 2 orang bayi mati setiap menit. $54 \%$ penyebab kematian bayi adalah latar belakang gizi. Kita bisa melihat data selanjutnya pada kondisi Indonesia saat ini : 27,3\% balita Indonesia gizi kurang, $8 \%$ dari mereka gizi buruk, $50 \%$ balita Indonesia kekurangan vitamin A, 48,1\% balita anemia gizi, $36 \%$ anak Indonesia tergolong pendek, 11,1\% anak sekolah menderita GAKY, 50\% ibu hamil kurang gizi. Berbagai faktor dapat mempengaruhi naik dan turunnya $\mathrm{AKB}$ dan AKI, diantaranya belum di manfaatkannya sarana pelayanan kesehatan seperti posyandu secara optimal oleh masyarakat.kesehatan masyarakat masih rendah dan sebaliknya (Depkes, 2009).

Di Provinsi Banten angka kematian ibu dan bayi menduduki posisi kelima secara nasional. Sedangkan Untuk di kabupaten Lebak kematian bayi dan balita menduduki urutan kedua dari 8 kabupaten yang ada di banten yaitu sebesar 383 (Profil Kesehatan 2012 Prov. Banten). Hasil survey data yang ditemukan di Puskesmas Mekarsari Lebak Banten Jumlah seluruh bayi dan balita berumur 0-59 bulan yang ada di 3 desa yaitu desa Mekar Sari, Citeras, Nameng terdapat 268 balita tetapi yang datang keposyandu hanya 120 balita sedangkan jumlah bayi yang berumur 0-59 bulan didesa mekar sari sebesar 157 bayi dan balita. Pencatatan dan pelaporan data SKDN didesa Mekar Sari (D/S) adalah 45 $\%$, apabila dibawah $80 \%$ maka dapat dikatakan partisipasi masyarakat untuk kegiatan pemantauan pertumbuhan dan perkembangan berat badan sangatlah rendah.

Hal ini berakibat pada balita tidak akan terpantau oleh petugas kesehatan ataupun kader posyandu, akan memungkinkan balita ini tidak diketahui pertumbuhan berat badannya.

Banyak faktor yang menyebabkan ibu tidak membawa anaknya ke posyandu yaitu tingkat partisipasi masyarakat memeriksakan kesehatan balitanya ke Pos Pelayanan Kesehatan Terpadu (Posyandu) masih rendah. Kondisi ini salah satunya dipengaruhi oleh cara pandang orang tua yang merasa anaknya tidak perlu lagi dibawa ke posyandu seiring dengan pertambahan umur, jarak tempuh posyandu, sibuk kerja atau tidak sempat membawa anak balitanya ke posyandu dan kurangnya pengetahuan tentang pentingnya pemantauan tumbuh dan kembang pada anak balita .

\section{Metode Penelitian}

Penelitian ini adalah studi 
observasional analitik yang menjelaskan faktor-faktor yang mempengaruhi kunjungan balita keposyandu. Rancangan penelitian ini menggunakan metode cross sectional dimana data hanya diambil satu kali (one time approach)

Populasi dalam penelitian ini adalah ibu yang mempunyai balita di wilayah kerja Puskesmas Desa Mekar Sari Lebak yang berjumlah 157 responden sedangkan sampel 113 responden. Data yang di peroleh penelitian ini menggunakan data primer yang diperoleh dengan menggunakan kuasioner.

\section{Hasil}

1. Analisis univariat

Tabel 5.1

Distribusi Responden menurut Perilaku Kunjungan Ibu Balita ke Posyandu di Desa Mekar Sari Lebak Banten Tahun 2016

\begin{tabular}{|c|c|c|}
\hline Perilaku Kunjungan & Jumlah & $\%$ \\
\hline Baik & 49 & 43,4 \\
\hline Kurang & 64 & 56,6 \\
\hline Jumlah & 113 & 100 \\
\hline
\end{tabular}

Dari table dapat dilihat bahwa ibu yang berprilaku baik keposyandu masih rendah sebanyak $43,4 \%$ dan ibu yang berprilaku kunjungan kurang keposyandu sebanyak $56,6 \%$. Angka ini menggambarkan bahwa sebagian besar ibu berprilaku kurang untuk membawa anak balitanya ke Posyandu. Adapun alasan mengapa ibu tidak datang ke
Posyandu dengan alasan anaknya sudah diimunisasi sebanyak $38 \%$, males datang ke posyandu $20 \%$, alasan sibuk kerja $18 \%$, alasan anak sakit 13\%, dan alasan paling sedikit adalah ibunya lupa $11 \%$.

Tabel 5.2

Distribusi Responden Faktor Predisposisi dan Fakor Pemungkin di Desa Mekar Sari Lebak, Banten, 2016

\begin{tabular}{|l|l|l|}
\hline Variabel & Jumlah & Persentase (\%) \\
& & \\
& & \\
\hline $\begin{array}{l}\text { Pendidikan } \\
\text { Tinggi }\end{array}$ & 30 & 26,5 \\
Rendah & 83 & 73,5 \\
\hline $\begin{array}{l}\text { Pekerjaan } \\
\text { Bekerja } \\
\text { Tidak Bekerja }\end{array}$ & 19 & 16,8 \\
\hline $\begin{array}{l}\text { Pengetahuan } \\
\text { Baik }\end{array}$ & 94 & 83,2 \\
Kurang & 43 & 38,1 \\
\hline Jarak & 70 & 61,9 \\
$\begin{array}{l}\text { Dekat } \\
\text { Jauh }\end{array}$ & 102 & 90,3 \\
\hline Umur Anak & 11 & 9,7 \\
01-12 bulan & 29 & 25,7 \\
12-60 bulan & 84 & 74,3 \\
\hline
\end{tabular}

\section{Berdasarkan table 5.2 diatas} diketahui bahwa dari 113 ibu yang berpendidikanya rendah lebih banyak yaitu 73,5\% dari pada ibu yang berpendidikan tinggi $26,5 \%$. Dan ibu yang tidak bekerja lebih banyak $(16,8 \%)$ dari pada ibu yang tidak bekerja $(83,2 \%)$. Untuk variable pengetahuan sebagian besar ibu mempunyai tingkat pengetahuannya rendah terhadap kegiatan posyandu yaitu $61,9 \%$ sedangkan ibu yang mempunyai tingkat pengetahuan baik terhadap kegiatan posyandu $43 \%$. Ibu yang jarak rumahnya 
dekat dengan posyandu lebih banyak 90,3\% dari pada ibu yang jarak rumahnya jauh dari posyandu. Pada Umur anak usia 12-60 bulan lebih banyak yang tidak datang ke Posyandu sebanyak $74,3, \%$ dari pada umur anak yang berumur 01-12 bulan $25,7 \%$

2. Analisis Bivariat

Tabel 5.3

Distribusi Responden antara factor predisposisi dan faktor pemungkin dengan perilaku kunjungan ibu balita ke Posyandu di Desa Mekar Sari Lebak Banten

\begin{tabular}{|c|c|c|c|c|c|c|c|c|}
\hline \multirow{3}{*}{ Variabel } & \multicolumn{4}{|c|}{$\begin{array}{c}\text { Perilakes Kunjung an Ibu Ke } \\
\text { Posyandu }\end{array}$} & \multicolumn{2}{|c|}{ Total } & \multirow{3}{*}{$\begin{array}{c}P \\
\text { Value }\end{array}$} & \multirow{3}{*}{$\begin{array}{c}\text { OR } \\
95 \% \mathrm{CI}\end{array}$} \\
\hline & \multicolumn{2}{|c|}{ Baik } & \multicolumn{2}{|c|}{ Kurang } & \multirow{2}{*}{$\mathrm{N}$} & \multirow{2}{*}{$\%$} & & \\
\hline & $\mathrm{N}$ & $\%$ & $\mathrm{~N}$ & $\%$ & & & & \\
\hline $\begin{array}{l}\text { Pendidilan } \\
\text { Tinggi } \\
\text { Rendah }\end{array}$ & $\begin{array}{l}21 \\
28\end{array}$ & $\begin{array}{c}70 \\
33,7\end{array}$ & $\stackrel{9}{55}$ & $\begin{array}{c}30 \\
663\end{array}$ & $\begin{array}{l}30 \\
83\end{array}$ & 100 & 001 & $\begin{array}{l}4,58 \\
(1,85- \\
11,3)\end{array}$ \\
\hline $\begin{array}{l}\text { Pekerjaan } \\
\text { Bekerja } \\
\text { TidakBekerja }\end{array}$ & $\begin{array}{l}12 \\
37\end{array}$ & $\begin{array}{l}63,2 \\
39,4\end{array}$ & $\begin{array}{c}7 \\
57\end{array}$ & $\begin{array}{l}36,8 \\
60,6\end{array}$ & $\begin{array}{l}19 \\
94\end{array}$ & 100 & 056 & $\begin{array}{l}2,64 \\
(0,95- \\
7.33)\end{array}$ \\
\hline $\begin{array}{l}\text { Pengetahuan } \\
\text { Baik } \\
\text { Kurang }\end{array}$ & $\begin{array}{l}27 \\
22\end{array}$ & $\begin{array}{c}63 \\
31,4\end{array}$ & $\begin{array}{l}16 \\
48\end{array}$ & $\begin{array}{c}37 \\
68,6\end{array}$ & $\begin{array}{l}43 \\
70\end{array}$ & 100 & $\infty 01$ & $\begin{array}{l}3,68 \\
(1,68 \\
8,17)\end{array}$ \\
\hline $\begin{array}{l}\text { Jarak } \\
\text { Delat } \\
\text { Janh }\end{array}$ & $\begin{array}{c}46 \\
3\end{array}$ & $\begin{array}{c}45 \\
273\end{array}$ & $\begin{array}{l}56 \\
8\end{array}$ & $\begin{array}{c}55 \\
72,7\end{array}$ & $\begin{array}{c}102 \\
11\end{array}$ & 100 & 210 & $\begin{array}{l}2.190 \\
(0,54 \\
8.73)\end{array}$ \\
\hline $\begin{array}{l}\text { Umw Anak } \\
01-12 \text { bulan } \\
12-60 \text { bulan }\end{array}$ & $\begin{array}{l}21 \\
28\end{array}$ & $\begin{array}{l}72,4 \\
33,3\end{array}$ & $\begin{array}{c}8 \\
56\end{array}$ & $\begin{array}{l}27,6 \\
66,7\end{array}$ & $\begin{array}{l}29 \\
84\end{array}$ & 100 & 000 & $\begin{array}{l}5,25 \\
(2.06 \\
13,33)\end{array}$ \\
\hline
\end{tabular}

1. Hubungan Pendidikan ibu dengan perilaku kunjungan ibu balita ke Posyandu

Dari table diatas menunjukan bahwa ibu balita yang berprilaku baik memiliki pendidikan tinggi lebih banyak (besar) dibandingkan dengan ibu yang berpendidikan rendah $(70 \%: 33,7 \%)$. Sebaliknya, dibandingkan dengan responden atau ibu dengan perilaku yang kurang memiliki pendidikan yang rendah lebih banyak $(66,3 \%)$.

Berdasarkan hasil uji chisquare diperoleh nilai $\mathrm{p}=001$ artinya ada hubungan antara pendidikan ibu dengan perilaku kunjungan ibu ke posyandu

2. Hubungan Pekerjaan ibu denganperilaku kunjungan ibu balita ke Posyandu

Dari tabel diatas menunjukan bahwa perilaku kunjungan ibu ke posyandu yang baik pada ibu bekerja 63,2 \% dan pada ibu yang tidak bekerja 39,4\%, sedangkan ibu yang perilakunya kurang pada kunjungan ke posyandu pada ibu yang bekerja sebesar 36,8 dan pada ibu yang tidak bekerja $60,6 \%$

Berdasarkan hasil uji chisquare diperoleh nilai $\mathrm{p}=056$ artinya tidak ada hubungan yang signifikan antara pekerjaan ibu dengan kunjungan ibu ke posyandu.

3. Hubungan pengetahuan ibu dengan perilaku kunjungan ibu balita ke Posyandu

Berdasarkan tabel diatas diketahui bahwa dari Ibu yang berprilaku baik terhadap kunjungan keposyandu memiliki pengetahuan yang baik ( 63\%) dan pengetahuannya kurang $(31,4 \%)$, sedangkan pada perilaku yang ibu yang kurang mempunyai pengetahuan yang baik $(37 \%)$, dan pengetahuan kurang $(68,6 \%)$.

Berdasarkan hasil uji chisquare diperoleh nilat $\mathrm{p}=001$ artinya ada 
hubungan antara pengetahuan ibu dengan perilaku kunjungan ibu ke Posyandu

4. Hubungan Jarak dengan perilaku

Berdasarkan tabel diatas diketahui bahwa dari Ibu yang berprilaku baik terhadap kunjungan keposyandu mempunyai jarak yang dekat dari rumah ke posyandu (45\%) dan jarak yang jauh $(27,3 \%)$, sedangkan pada perilaku yang ibu yang kurang jarak rumah yang dekat ke posyandu (55\%), dan jauh keposyandu (72,7\%). Berdasarkan hasil uji chisquare diperoleh nilat $\mathrm{p}=210$ artinya tidak ada hubungan antara jarak dari rumah dengan perilaku kunjungan ibu ke Posyandu

Berdasarkan hasil penelitian menunjukkan tidak ada hubungan antara variable jarak dengan perilaku kunjungan ibu ke posyandu dengan nilai $\mathrm{p}=0,210$ yang artinya tidak ada perbedaan antara ibu yang mempunyai rumah yang mempunyai jarak tempuh dekat dengan posyandu dengan ibu yang mempunyai jarak tempuh yang jauh ke posyandu.

5. Hubungan umur anak dengan perilaku kunjungan ibu balita ke Posyandu

Berdasarkan tabel diatas diketahui bahwa dari Ibu yang berprilaku baik terhadap kunjungan keposyandu sebagian besar yang mempunyai anak balita usia 0112 bulan $(72,4 \%)$, sedangkan umur 12-60 bulan $(33,3 \%)$, pada perilaku yang kurang pada kunjungan ibu ke Posyandu pada balita usia 01-12 (27,6\%), sedangkan pada pada usia $12-60(66,7 \%)$

Berdasarkan hasil uji chisquare diperoleh nilat $\mathrm{p}=000$ artinya ada hubungan antara umur anak dengan perilaku kunjungan ibu ke Posyandu.

Berdasarkan hasil penelitian menunjukkan anak yang berumur 01-12 bulan sebanyak $25,7 \%$, anak yang berumur $12-60$ bulan sebanyak 74,3\%. Hasil uji chi-square menunjukkan ada hubungan yang bermakna antara umur anak dengan perilaku kunjungan ibu ke posyandu dengan nilai $\mathrm{p}=0,00$ yang artinya ibu yang mempunyai anak berumur 13-60 bulan banyak yang tidak datang ke posyandu.

Hasil penelitian ini sesuai dengan penelitian Yuryanti (2010) yang menyatakan ada hubungan bermakna antara umur anak dengan perilaku kunjungan ibu ke Posyandu. Dari hasil penelitian menunjukan bahwa semakin bertambah usia anak balita semakin berkurang kunjungan ke Posyandu, dikarenakan ibu tidak membawanya karena anaknya sudah mendapatkan imunisasi lengkap sehingga tidak perlu lagi untuk datang ke Posyandu atau karena anak sudah masuk Paud atau TK. 


\section{Analisis Multivariat}

Hasil analisis multivariat regresi logistik

Faktor- faktor Yang Berhubungan Dengan

Kunjungan Ibu Balita Ke Posyandu Didesa

Mekarsari Lebak Banten

\begin{tabular}{|l|c|c|c|c|c|}
\hline Variabel & B & P & OR & \multicolumn{2}{|c|}{$95 \% \mathrm{CL}$} \\
\cline { 4 - 6 } & & & & Lower & Upper \\
\hline Pendiditan & 1.532 & 002 & 4.630 & 1.782 & 12.029 \\
\hline Umur Analk & 1.668 & 001 & 5.300 & 1.995 & 14.061 \\
\hline Constanta & & & & & \\
\hline \multicolumn{2}{|c|}{ Dari tabel diatas dapat disimpulkan }
\end{tabular}

bahwa ;

Variabel yang berpengaruh terhadap perilaku kunjungan ibu balita ke Posyandu adalah factor pendidikan ibu dan umur anak. Kekuatan hubungan dapat dilihat dari nilai OR. Kekuatan hubungan dari yang terbesar ke yang terkecil adalah Umur anak $(\mathrm{OR}=5,3)$, pendidikan $(\mathrm{OR}=46)$.

Dari kedua variable independen tersebut, maka variable umur anak adalah variable yang paling dominan berhubungan dengan prilaku ibu untuk datang ke Posyandu, dengan OR (5.300). Hal ini berarti bahwa ibu yang memiliki anak yang berumur 01-12 bulan berpeluang 5 kali untuk berprilaku baik untuk datang ke posyandu, dibandingkan ibu dengan yang memiliki anak yang berusia 12-60 bulan, setelah dikontrol variable pendidikan.

\section{Pembahasan}

1. Pendidikan

Menurut Suwarno (1992) dalam Nursalam (2001) pendidikan berarti bimbingan yang diberikan oleh sesorang terhadap orang lain menuju kearah suatu cita-cita tertentu, semakin tinggi pendidikan orang semakin tinggi tingkat pengetahuanyaHasil penelitian yang dilakukan didapatkan sebagian besar ibu yang berpendidikan rendah sebanyak 83 responden $(73,5 \%)$. Hasil penelitian didapatkan ada hubungan antara pendidikan dengan perilaku ibu terhadap kunjungan ke posyandu di desa Mekar Sari Lebak Banten dengan nilai $p$ value $0,001<\alpha(0,05)$ dan nilai OR 4.583 yang berarti bahwa ibu yang pendidikannya tinggi mempunyai peluang 4.583 untuk berkelakuan baik dibandingkan dengan ibu yang pendidikannya rendah

Pendidikan ibu kebanyakan yang rendah disebabkan karena pendidikan dasar pada saat ini sampai jenjang SMP maka diperlukan pendidikan yang lebih lagi yaitu sampai SMA dan perguruan tinggi. Ibu yang berpendidikan tinggi disebabkan tuntutan pendidikan pada era ini adalah sampai pada jenjang perguruan tinggi dan kemunduran usia menikah.

Penelitian ini sejalan dengan hasil penelitian Koto N (2011) dan Elida (2012) yang menyatakan terdapat hubungan yang 
bermakna antara pendidikan dengan perilaku ibu untuk datang ke posyandu.

Pendidikan ibu berhubungan dengan perilaku ini disebabkan pendidikan mempengaruhi pola fikir seseorang dan membantu seseorang menyerap informasi yang diberikan sehingga dapat mengubah perilaku seseorang. Walaupun hanya berpendidikan dasar tetapi pengaruh kepercayaan terhadap tenaga kesehatan membuat responden melakukan kunjungan ke posyandu. Responden yang berpendidikan tinggi masih ada yang prilaku yang kurang untuk datang ke posyandu ini disebabkan meskipun pendidikan tinggi dan memiliki kemampuan untuk menyerap informasi lebih banyak dan lebih mengutamakan kesehatannya daripada ibu yang berpendidikan rendah tetapi ibu tidak mempunyai waktu untuk melakukan kunjungan ke posyandu. Pendidikan dapat mempengaruhi seseorang termasuk juga perilaku seseorang akan pola hidup.

\section{Pekerjaan}

Hasil penelitian didapatkan sebagian besar ibu tidak bekerja atau ibu rumah tangga sebanyak 94 (83,2\%). Kebanyakan ibu tidak bekerja atau sebagai ibu rumah tangga disebabkan ibu memiliki balita yang harus diasuh dan suami telah mencukupi kebutuhan rumah tangga mereka. Ibu tidak bekerja atau ibu rumah tangga mempunyai waktu yang banyak dan cukup untuk membawa balitanya ke posyandu. Pada penelitian ini ada ibu yang bekerja. Ibu bekerja mempunyai kesibukan dan waktu yang terbatas untuk bersama putra-putrinya dan masa cuti yang diberikan hanya 3 bulan sehingga lebih besar kemungkinan tidak dapat membawa balitanya ke posyandu. Pekerjaan yang dimiliki seseorang atau lebih ke aktifitas sehari-hari seseorang dapat menghambat kunjungan ke posyandu bila di hari posyandu ibu harus bekerja. Menurut Barthos (2001) ada beberapa pekerjaan ibu yaitu sebagai PNS, karyawan swasta, wiraswasta, petani, buruh. Ada juga ibu yang tidak bekerja atau sebagai ibu rumah tangga.

Hasil penelitian didapatkan tidak ada hubungan antara pekerjaan dengan perilaku ibu terhadap kunjungan ke posyandu di desa Mekar Sari Lebak Banten, dengan nilai $p$ vanlue $0,56>\alpha(0,05)$. Tidak adanya hubungan disebabkan baik ibu bekerja maupun tidak bekerja masih ada yang tidak berkunjung ke posyandu disebabkan banyak factor takut anaknya untuk diimunisasi dikarenakan adnya vaksin palsu, menggangap anaknya yang telah diimunisasi lengkap tidak perlu lagi dibawa ke posyandu, pada saat posyandu anaknya lagi sakit, atau ibu lupa bahwa adanya posyandu. Nilai odd rasio pada penelitain ini 2.64 yang artinya ibu yang 
bekerja berprilaku baik 2,64 kali lebih besar untuk datang ke posyandu daripada ibu tidak bekerja. Hal ini dapat dilihat dari hasil penelitian dimana responden yang tidak bekerja malahan lebih banyak tidak datang ke posyandu daripa ibu bekerja

\section{Pengetahuan}

Hasil penelitian ini sesuai dengan penelitian Elida (2012) dan yuryanti (2010) yang menyatakan tingginya pengetahuan ibu tentang posyandu tersebut membuat mereka selalu membawa anaknya ke Posyandu agar mudah untuk memantau tumbuh kembangnya Dari hasil penelitian ini pada ibu yang pengetahuannya kurang, maka jumlah kunjungan juga kurang, Hal ini dikarenakan kurangnya pengetahuan ibu tentang kegiatan-kegiatan yang ada di Posyandu

Nilai odd rasio pada penelitain ini 3.682 yang artinya ibu yang pengetahuannya baik 3,682 kali lebih besar untuk datang ke posyandu daripada ibu pengetahuannya kurang. Hal ini dapat dilihat dari hasil penelitian dimana responden yang pengetahuannya kurang lebih banyak tidak datang ke posyandu daripa ibu yang pengetahuannya baik.

\section{Jarak}

\section{Berdasarkan hasil penelitian} menunjukkan tidak ada hubungan antara variable jarak dengan perilaku kunjungan ibu ke posyandu dengan nilai $\mathrm{p}=0,210$ yang artinya tidak ada perbedaan antara ibu yang mempunyai rumah yang mempunyai jarak tempuh dekat dengan posyandu dengan ibu yang mempunyai jarak tempuh yang jauh ke posyandu.

Hal ini sesuai dengan Elida (2012) dan Sambas (2002) yang menyatakan tidak ada hubungan ibu-ibu yang mempunyai jarak dekat dengan jarak jauh ke Posyandu. Dalam hal ini berbeda dengan penelitian yang dilakukan Yuryanti (2010) yang menyatakan ada hubungan yang bermakna antara jarak tempuh dengan tempat posyandu.

\section{Umur Anak}

Berdasarkan hasil penelitian menunjukkan anak yang berumur 01-12 bulan sebanyak $25,7 \%$, anak yang berumur 12-60 bulan sebanyak 74,3\%. Hasil uji chisquare menunjukkan ada hubungan yang bermakna antara umur anak dengan perilaku kunjungan ibu ke posyandu dengan nilai $\mathrm{p}=0,00$ yang artinya ibu yang mempunyai anak berumur 13-60 bulan banyak yang tidak datang ke posyandu.

Hasil penelitian ini sesuai dengan penelitian Yuryanti (2010) yang menyatakan ada hubungan bermakna antara umur anak dengan perilaku kunjungan ibu ke Posyandu. Dari hasil penelitian menunjukan bahwa semakin bertambah usia anak balita semakin berkurang kunjungan ke Posyandu, dikarenakan ibu 
tidak membawanya karena anaknya sudah mendapatkan imunisasi lengkap sehingga tidak perlu lagi untuk datang ke Posyandu atau karena anak sudah masuk Paud atau TK.

\section{Simpulan}

Dari hasil penelitian bulan Maret November 2016 di Desa Mekar Sari LebakBanten pada 113 responden diperoleh kesimpulan sebagai berikut :

1. Sebagian besar responden ( ibu ) yang berpendidikan rendah $73,5 \%$

2. Sebagian besar responden (ibu ) tidak bekerja $83,2 \%$

3. Sebagian besar responden (ibu) pengetahuannya kurang $61,9 \%$

4. Sebagian besar responden (ibu ) jarak tempuhnya dekat dari rumah keposyandu $(90,3 \%$

5. Sebagian besar responden memiliki anak balita yang berusia $74,3 \%$

Dari 5 variabel tersebut terdapat 3 variabel yang berhubungan dengan faktor kunjungan ibu ke Posyandu yaitu pendidikan dengan nilai $\mathrm{p}=0.001$, pengetahuan $\mathrm{p}=0,001 \mathrm{dan}$ umur anak $\mathrm{p}=0,000$, sedangakan dari ketiga variable tersebut factor yang sangat mempengaruhi kunjungan ibu ke Posyandu adalah umur anak balita.

\section{Daftar Pustaka}

BR Purba Elida Hairunida,2012." Faktorfaktor yang berhubungan dengan perilaku kunjungan ke posyandu pada ibu balita diwilayah kerja Puskesmas Pancoran Kota Depok"

Chandra Budiman, 2008, Metodelogi

Peneliat Kesehatan. Jakarta. EGC

Departemen Kesehatan RI ( 2009 ). Survey Demografi dan Kesehatan Indonesia 2007

Departemen Kesehatan RI (2011). Pedoman Umum Pengelolaan Posyandu

Dinas Kesehatan Prov Banten ( 2012). Profil Kesehatan Provinsi Banten tahun 2012

Hartono Sutanto Priyo.dkk, 2013, Statistik Kesehatan. Jakarta: Raja Grafindo Persada

Hasan Nur Ain Oliviana.2013. "Faktorfaktor yang berhubungan dengan partisipasi ibu balita dalam kegiatan posyandu di Kelurahan Kayu Merah Kec Limboto Kabapaten Gorotalo, UNG

Hidayat Aziz Alimul, 2007, Metode Penelitian Kebidanan dan Teknik Analisi Data. Jakarta: Salemba Medika

Hidayat Aziz Alimul, 2008, Pengantar Ilmu Kesehatan Anak untuk Pendidikan Kebidanan, Jakarta : Salemba Medika

http://www.depkes.go.id/resources/downlo $\mathrm{ad} /$ promosi-kesehatan/buku-sakuposyandu.pdf

Maryunari Anik,2010, Ilmu Kesehatan Anak Dalam Kebidanan, Jakarta : Trans Info Media

Meilani Niken,dkk, 2009, Kebidanan Komunitas, Yogyakarta : F.Tramaya

Notoadmodjo Soekidjo. 2010, Metodelogi Penelitian Kesehatan. Jakarta: Rineka Cipta.

Sudaryono, 2011, Metode penelitian pendidikan. Banten: Dinas Pendidikan Prov Banten

Tando Naomy Marei, 2013, Organisasi dan Manajemen Pelayanan Kesehatan, Jakarta : Inmedia 